\title{
Improving intraoperative handoffs for ambulatory anesthesia: challenges and solutions for the anesthesiologist [Corrigendum]
}

Dexter F, Osman BM, Epstein RH. Local Reg Anesth. 2019, 12:37-46.

On page 38, Table 1, Summary of principal findings row, column 4 the text "(odds ratio $0.95,95 \% \mathrm{CI}$ 9.895 to $1.022, P=0.19)$ " should read "(odds ratio $0.95,95 \%$ CI 0.895 to $1.022, P=0.19$ )" (i.e., change 9.985 to 0.895$)$ and " $(0.933,95 \%$ CI $0.890-9.977$,
$P<0.0001)$ " should read “(0.933, 95\% CI 0.890-0.977, $P<0.0001$ )" (i.e., change 9.977 to 0.977 ). On page 39 , column 2, paragraph 3 , the matching change to the text is for "(adjusted odds ratio 0.95, 95\% CI 9.895-1.022, $P=0.19)$ " to be "(adjusted odds ratio $0.95,95 \% \mathrm{CI}$ 0.895-1.022, $P=0.19$ )" and "(odds ratio $=0.933,95 \% \mathrm{CI}$ $0.890-9.977, P<0.0001)$ " to be "(odds ratio=0.933, 95\% CI $0.890-0.977, P<0.0001)$ '.

\section{Publish your work in this journal}

Local and Regional Anesthesia is an international, peer-reviewed, open access journal publishing on the development, pharmacology, delivery and targeting and clinical use of local and regional anesthetics and analgesics. The journal welcomes submitted papers covering original research, basic science, clinical studies, reviews \& evaluations, guidelines, expert opinion and commentary, case reports and extended reports. The manuscript management system is completely online and includes a very quick and fair peer-review system, which is all easy to use. Visit http://www.dovepress.com/testimonials. php to read real quotes from published authors. 